The Science of the Total Enoironment

Elsevier Publishing Company, Amsterdam - Printed in Belgium

\title{
PCB-INDUCED SUPPRESSION OF THE HUMORAL AND CELL-MEDIATED IMMUNITY IN GUINEA PIGS
}

\section{J. G. VOS and LIDEKE VAN DRIEL-GROOTENHUIS}

Institute of Veterinary Pathology and Institute of Veterinary Pharmacology and Toxicology, University of Utrecht, Biltstraat 172, Utrecht (The Netherlands)

(Received August 10th, 1972)

\section{ABSTRACT}

The effect of PCB feeding at levels of $0,10,50$ and $250 \mathrm{ppm}$, on the humoral and cell-mediated immune response is described. Three experiments were carried out with guinea pigs. A suppression of the humoral immunity, after stimulation with one dose of tetanus toxoid (alum-adsorbed) was found at the $50 \mathrm{ppm}$ level. The antitoxin titres were statistically significantly decreased as determined with the passive haemagglutination test. Also, the number of tetanus antitoxin-producing cells in the stimulated popliteal lymph nodes were reduced, as was shown with the indirect fluorescent antibody technique. In a second experiment, animals were immunized with two doses of tetanus toxoid. A decreased immunological response was observed again at the $50 \mathrm{ppm}$ level using single radial immuno-diffusion and fluorescent antibody techniques. In addition lymphopenia was found. In the third experiment the cell-mediated immunity was stimulated with Freund's Complete Adjuvant. The skin reactions after tuberculination, as a parameter of the cell-mediated immunity, were statistically significantly reduced at the $50 \mathrm{ppm}$ level. In all 3 experiments, organ weights were recorded and histological studies were performed. Stress was not considered responsible for the reduced immunological responses. A high mortality occurred at the $250 \mathrm{ppm}$ level. Cachexia and depletion of the lymphoid system and liver damage were the most important findings in these animals. PCB contents of pooled liver samples are given.

\section{INTRODUCTION}

Polychlorinated biphenyls (PCBs) have become ubiquitous contaminants of the global ecosystem. Commercial preparations, consisting of a number of diffe1ently chlorinated biphenyls, are extremely stable and are only slightly soluble in water. They are persistent and accumulate in food chains.

An indication for an immunosuppressive activity of PCBs was obtained from a number of toxicity studies which were undertaken to evaluate the hazards of PCBs. Small spleens were noted in chickens fed with PCB (Flick et al., 1965), showing 
atrophy of the lymphoid system (Vos and Koeman, 1970). A reduced number of white blood cells, atrophy of the cortex of the thymus, and a reduction in the number of germinal centres in the spleen and lymph nodes were found after dermal application of high doses of PCB in rabbits (Vos and Beems, 1971). An interaction of PCBs with duck hepatitis virus was found by Friend and Trainer (1970): challenging of ducklings with this virus resulted in a significantly higher mortality of the PCBexposed animals when compared with the controls. Hansen et al. (1971) suggest that chronic exposure to PCB increases the susceptibility of fish to disease.

The purpose of a previous study (Vos and De Roij, 1972) was to investigate whether or not these findings were due to an immunosuppressive action. In that study, a reduction in the number of $\gamma$-globulin-containing cells was found in the stimulated popliteal lymph node using the direct fluorescent antibody technique. Also the serum $\gamma$-globulin level was reduced.

The present study concerns the effect of PCB on the humoral immunity again after stimulation with tetanus toxoid using more proper techniques (indirect fluorescent antibody technique and serum antitoxin titre determination). Moreover the effect of PCB on the cell-mediated immunity (the delayed hypersensitivity to tuberculin) is investigated.

\section{METHODS}

The technical PCB preparations, which contain an average of $60 \%$ chlorine, were obtained from Farbenfabriken Bayer AG, Leverkusen, G. F. R. (Clophen A 60; Lot. No. 912434) and the Monsanto Chemical Co., St. Louis, U. S. A. (Aroclor 1260; Lot. No. Ak-3). The former sample appeared to contain traces of highly toxic chlorinated dibenzofurans as was found in pathological, toxicological and chemicalanalytical studies (Vos and Koeman, 1970; Vos et al., 1970; Vos and Beems, 1971). In one of the experiments both the Clophen and the Aroclor sample were used to determine possible differences in their effects on the immune system. Three experiments were conducted beginning with 3-4 week-old albino guinea pigs with body weights of about $225 \mathrm{~g}$; two investigations concerning the humoral immune response and one concerning the effect of PCB treatment on the cell-mediated immune system. Standard diet (Hope Farms, Woerden) and water were provided ad libitum and weight gain was determined weekly. The significance of differences between the treated and the control groups was calculated on a one-tail significance level, using the Wilcoxon test for 2 unrelated samples (Van der Waerden, 1957).

Experiment $A$. Effect of PCB feeding on the humoral immune response in male guinea pigs after stimulation with one dose of tetanus toxoid

Forty animals, housed in groups of 5 , were distributed at random into 4 groups receiving diets containing 0, 10, 50 and 250 ppm PCB (Clophen A 60). After 3 weeks, all animals received a subcutaneous injection $(0.1 \mathrm{ml})$ of alum-adsorbed tetanus toxoid ( $5 \mathrm{Lf}$ tet.tox. $+1.5 \mathrm{mg} \mathrm{ALPO}{ }_{4}$ ) (National Institute of Public Health, Bilthoven) in the right footpad to stimulate the humoral immunity and in particular 
the draining popliteal lymph node. The animals were killed with carbon dioxide gas 6 days after the immunization. Blood was taken from the heart for the determination of tetanus-antitoxin titres using the passive haemagglutination test (Stavitsky, 1954). In this way, especially the immunoglobulin $M$ (IgM) molecules are titrated, which are efficient agglutinating agents that appear early during the primary response. Necropsy was carried out on all animals which were killed or died during the experiment. The latter were also subjected to a gross inspection under ultraviolet light, to detect red fluorescence, indicating porphyria (Vos and Koeman, 1970; Vos et al., 1971). The popliteal lymph-nodes were weighed and fixed in $96 \%$ ethanol for 16-24 h at $4{ }^{\circ} \mathrm{C}$. The tissue was dehydrated and embedded in Paraplast according to Weir (1967).

For the indirect fluorescent antibody technique, the sections were incubated with tetanus toxoid ( $150 \mathrm{Lf} / \mathrm{ml} \mathrm{PBS}$ ) for $35 \mathrm{~min}$, washed for $30 \mathrm{~min}$ in PBS, and then incubated for $35 \mathrm{~min}$ with fluorescein isothiocyanate (FITC)-labeled rabbit anti-tetanus serum. Then the sections were again washed with PBS for $2 \mathrm{~h}$ and mounted with UVAK. The immunological specificity of staining was checked by performing appropriate controls. The sections were studied with a fluorescence microscope (Zeiss, equipped with a special FIFC exciting interference filter KP 500). The number of tetanus antitoxin-containing cells was graded from - to ++++ . The thymus, spleen, liver, adrenals, thyroid and gonads were weighed and fixed in Carnoy fluid for $24 \mathrm{~h}$ at $4{ }^{\circ} \mathrm{C}$ or in buffered $10 \%$ formalin, and embedded in Paraplast. Sections were stained with methyl green-pyronin (Elias, 1969) and with haematoxylin-eosin. The PCB concentration in pooled liver samples was determined by gas chromatography, as described earlier (Vos et al., 1971).

Experiment $B$. Effect of $P C B$ feeding on the humoral immune response in female guinea pigs after stimulation with two doses of tetanus toxoid

Forty animals were distributed at random into 4 groups that were fed diets containing 0, 10 (Clophen A 60), 50 (Clophen A 60), and 50 (Aroclor 1260) ppm PCB. A primary and secondary antigenic stimulation with tetanus toxoid $(5 \mathrm{Lf})$ was given after 3 and 5 weeks. The experiment was terminated after 6 weeks. The same methods were used as in experiment $\mathbf{A}$, except for the antitoxin titre determinations. In this case a modified single radial immunodiffusion technique (Mancini et al., 1965) was used: the agar contained suitably diluted tetanus toxoid and the serum diffused from the well. The surface of the ring is roughly equivalent to the quantity of immunoglobulin $\mathrm{G}(\mathrm{IgG})$ antibodies, since these antibodies have relatively the highest titres after a secondary challenge. In addition, leucocyte counts and differential leucocyte counts were made.

Experiment $C$. Effect of PCB feeding on the cell-mediated immunity in female guinea pigs after stimulation with Freund's Complete Adjuvant

Thirty animals were distributed at random into 3 groups that received diets containing 0,50 and $250 \mathrm{ppm}$ PCB (Clophen A 60). After 3 weeks, the animals were given a subcutaneous injection $(0.05 \mathrm{ml})$ of Complete Freund's Adjuvant (Difco) 
in the right footpad. After 47 days a tuberculin injection was given intradermally $(0.1 \mathrm{ml}$ avian tuberculin PPD diluted $1: 10$ with $0.9 \% \mathrm{NaCl}$, Central Veterinary Institute, Rotterdam). The diameter of the skin reaction, as a parameter of the cellmediated (delayed type) hypersensitivity, was measured after 24 and $48 \mathrm{~h}$. The animals were killed after 49 days. Microscopic examination was also made from the intradermal lesions. Relative surface estimations of the cortex of the thymi were done according to the point-counting principles of Hennig (Weibel, 1963).

\section{RESULTS}

\section{Experiment $A$}

The weight gain of the animals is given in Fig. 1, which shows that PCBfeeding did not affect the growth at the 10 and $50 \mathrm{ppm}$ level. Organ weights and organ: body weight ratios of the popliteal lymph node, thymus, spleen, adrenals, testicles

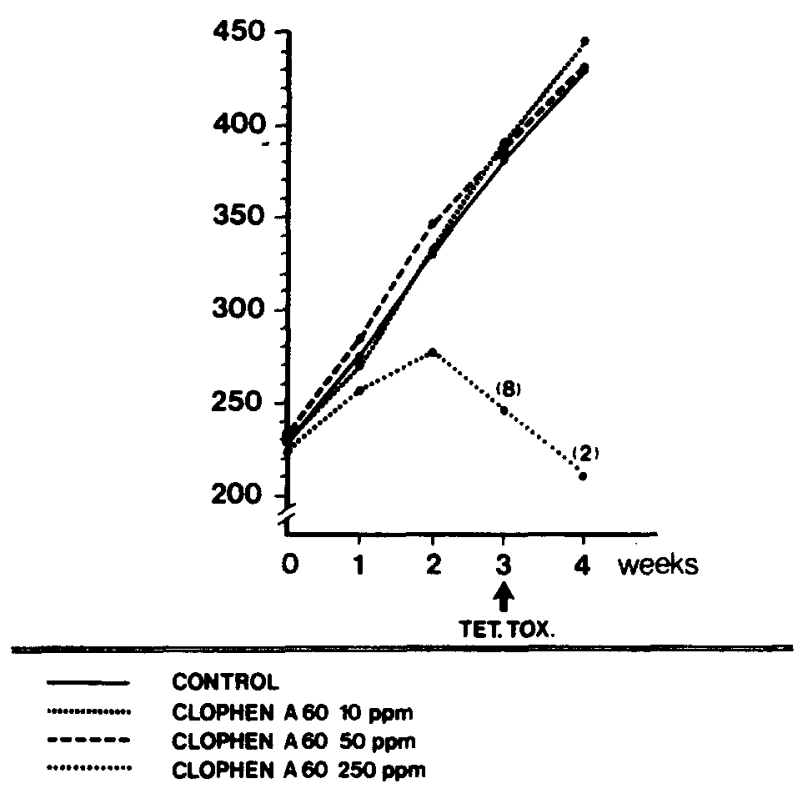

Fig. 1. Weight gain of tetanus toxoid-stimulated male guinea pigs fed PCB for 4 weeks, and of controls (Experiment $A$ ).

and thyroid of the killed animals of the 0,10 , and $50 \mathrm{ppm}$ group did not differ significantly. Absolute and relative liver weights were significantly increased in the 10 and $50 \mathrm{ppm}$ group. Serum antitoxin titres are given in Table I, showing significantly reduced values at the $50 \mathrm{ppm}$ level. A dose-related decrease can already be noted at the $10 \mathrm{ppm}$ level. The results of the indirect fluorescent antibody technique on popliteal lymph nodes are given in Fig. 2. As shown in this diagram, the decreased antibody formation is correlated with the level of PCB feeding. At the $250 \mathrm{ppm}$ level no antitoxin production was found in the 4 animals examined ( 2 killed and 2 which died on the last day). 
TABLE I

EFFECT OF PCB FEEDING ON HAEMAGGLUTINATION TITRES

IN MALE GUINEA PIGS STIMULATED WITH ONE DOSE OF

TETANUS TOXOID (Experiment $A$ )

\begin{tabular}{cll}
\hline $\begin{array}{l}\text { Dietary conc. of } P C B \\
\text { (Clophen } A \text { 60) }(p p m)\end{array}$ & $\begin{array}{l}\text { No. of } \\
\text { animals }\end{array}$ & \begin{tabular}{l} 
Haemagglutination $_{\text {titres }^{a}}$ \\
\hline 0
\end{tabular} \\
\hline 0 & 10 & $30.8(4-64)$ \\
50 & 10 & $13.2(4-32)$ \\
& 10 & $7.2(4-16)^{b}$
\end{tabular}

- Mean values; the range is given in parentheses. The antibody production (particularly $\operatorname{IgM}$ ) is expressed as reciprocal haemagglutination titre.

- $P \leqslant 0.005$.
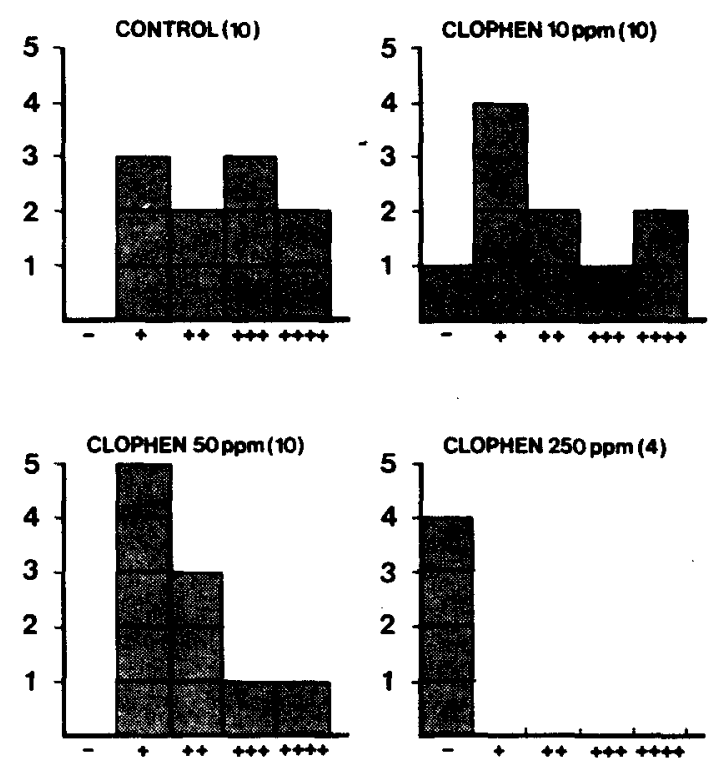
- to $++++=$ A comparative estimate of the number of tetanus-antitoxin producing cells The number of animals is given in parentheses

Fig. 2. Tetanus antitoxin-containing cells in popliteal lymph nodes of male guinea pigs fed PCB for 4 weeks and of controls (Experiment $A$ ).

On histological examination of methyl green-pyronin and haematoxylineosin stained sections of spleen, thymus and adrenal, no effect of PCB treatment at the 10 and $50 \mathrm{ppm}$ level was seen. In the livers of the $50 \mathrm{ppm}$ group, the presence of single cell necrosis, nuclear enlargement, basophilic cytoplasm and peripheral and perinuclear displacement of presumably cell organelles were rarely seen. 
A mortality of $80 \%$ was found at the $250 \mathrm{ppm}$ level (Fig. 1) with 2 animals dying on the last day of the experiment. Terminal body weights were about $50 \%$ of the weights of the controls. The animals were cachectic and showed roughening of the fur, though the food intake during the experiment continued at a reasonable level. Macroscopic red fluorescence under ultraviolet light, indicating porphyria, was not seen in the tissues of the animals that died.

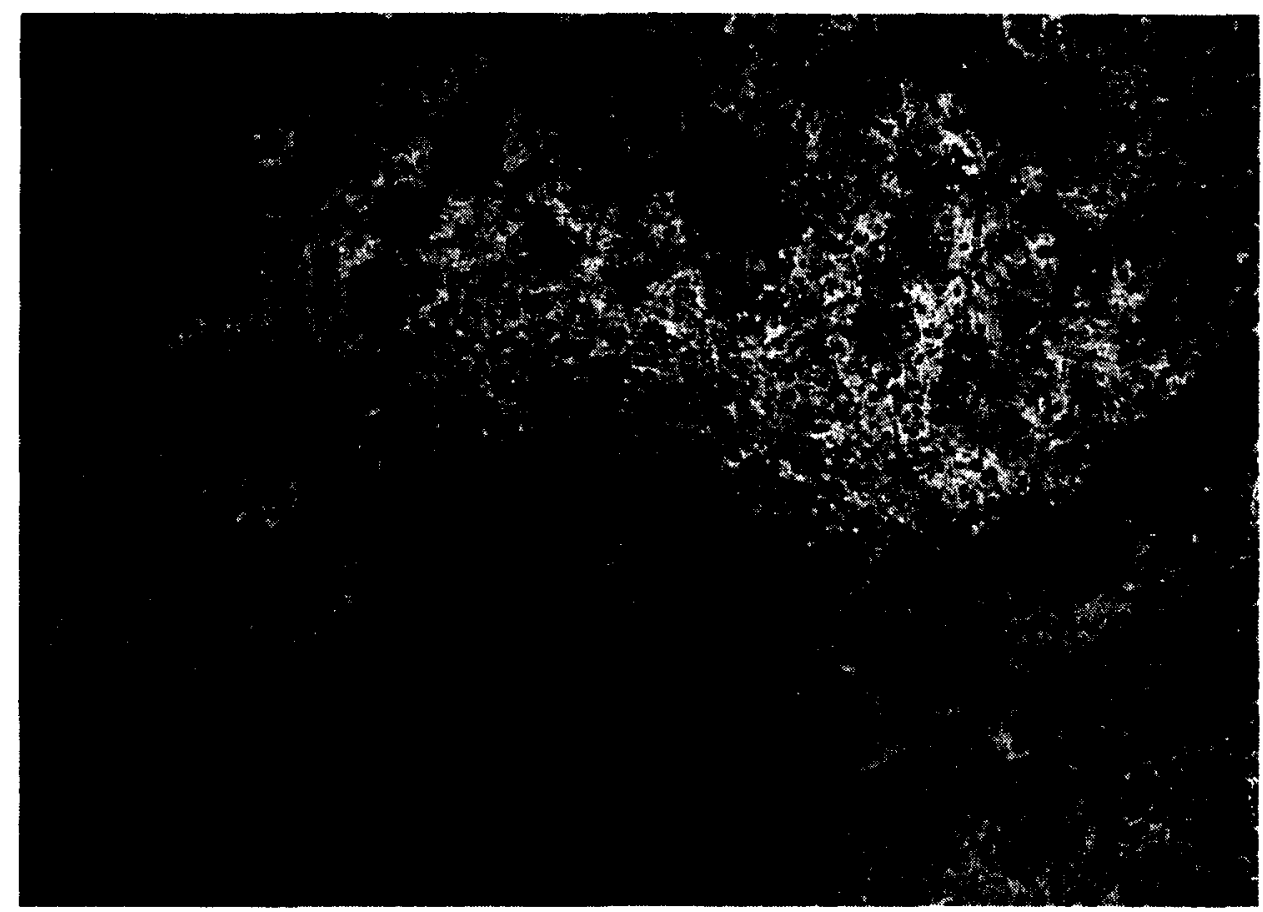

Fig. 3. Spleen of a control animal of Experiment $A$. Note the large number of plasma cells in the cords of Billroth (arrow), and the well developed follicle (F) and periarteriolar lymphocyte sheath (PALS). Methyl green-pyronin; × 150.

The weights of the popliteal lymph glands and thymi were remarkably low: about $20 \%$ and $25 \%$ of the controls, respectively. Spleen weights were also reduced but showed a large variation. A small reduction was noted in the weights of the liver and testicles; adrenal weights were somewhat increased. No effect was noted on brain, kidney and thyroid weight. On histological examination, a nearly total lymphocyte depletion was found in the cortex of the thymi. In the spleens (Figs. 3 and 4) of the two killed $250 \mathrm{ppm}$ animals, the number of plasma cells in the cords of Billroth was very strongly reduced. In addition, a reduction in the number and size of the follicles, with less pyroninophilic cells, as well as in the size of the periarteriolar lymphocyte sheats (PALS) was seen. Another finding was the presence of haemosiderin pigment in the red pulp, probably due to an increased breakdown of red blood cells or of myoglobin. In the livers of the high dose group, a lobular structure could be noted macroscopically. At microscopic examination, centrolobular liver degenera- 


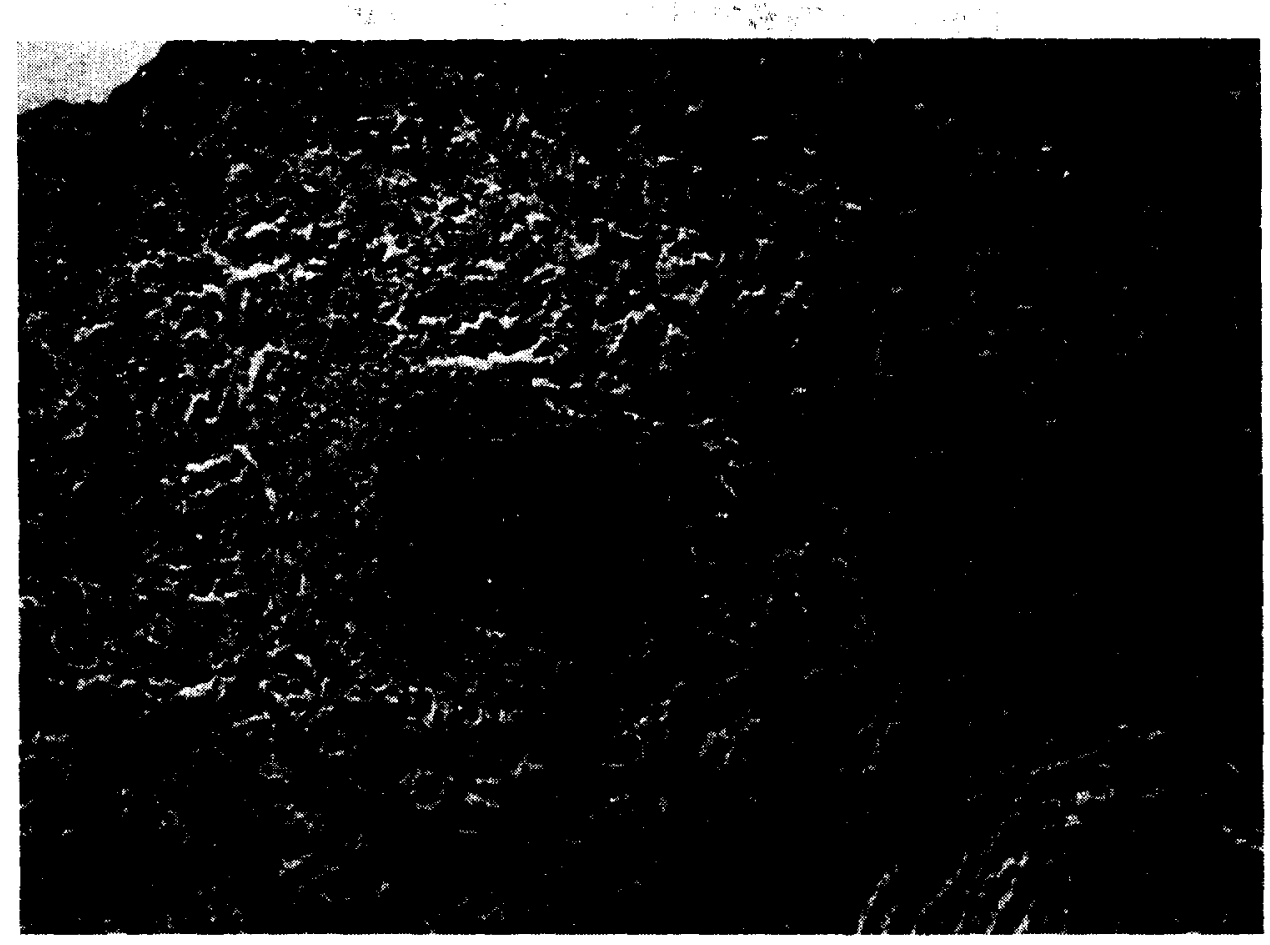

Fig. 4. Spleen of killed animal of the $250 \mathrm{ppm}$ group of Experiment $A$. Only a small number of plasma cells are present in the cords of Biliroth. Note the reduced size of follicle (F) and PALS. Haemosiderin pigment (arrow) is scattered over the red pulp. Methyl green-pyronin; $\times 150$.

tion and liver cell atrophy, cell necrosis and nuclear enlargement was noted. Also an activation of the Kupffer cells was seen. No evidence of damage was found in the sections of the other organs. Liver residue data are given in Table II.

\section{TABLE II}

PCB CONTENTS IN POOLED LIVER SAMPLES

OF KILLED GUINEA PIGS

\begin{tabular}{lllc}
\hline Experiment & $\begin{array}{l}\text { Dietary conc. } \\
\text { of PCB (ppm) }\end{array}$ & $\begin{array}{l}\text { No. of } \\
\text { animals }\end{array}$ & $\begin{array}{l}\text { Liver PCB } \\
\text { contents (ppm) }\end{array}$ \\
\hline A (4 weeks) & 0 & 10 & $<0.1$ \\
& 10 (Clophen A 60) & 10 & 1.1 \\
& 50 (Clophen A 60) & 10 & 6.7 \\
B (6 weeks) & 250 (Clophen A 60) & $4^{a}$ & 38 \\
& 0 & 9 & $<0.1$ \\
& 10 (Clophen A 60) & 10 & 1.7 \\
& 50 (Clophen A 60) & 10 & 9.1 \\
C (7 wceks) & 50 (Aroclor 1260) & 10 & 10.3 \\
& 0 & 10 & $<.1$ \\
& 50 (Clophen A 60) & 10 & 14.7 \\
\hline
\end{tabular}

a Including the two animals that died on the last day of the experiment. 


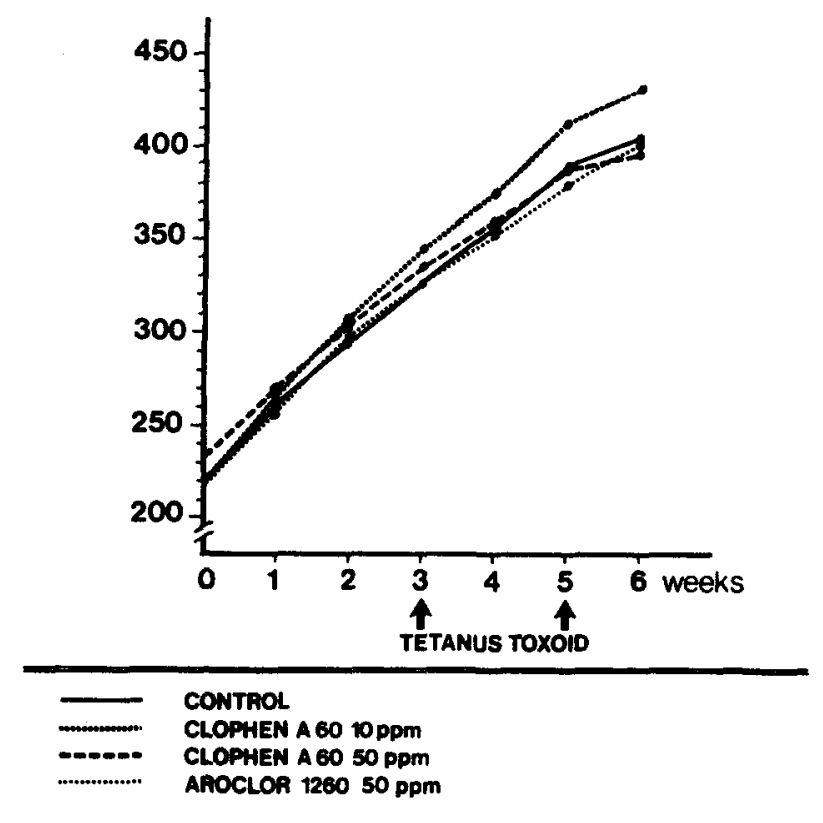

Fig. 5. Weight gain of tetanus toxoid-stimulated female guinea pigs fed PCB for 6 weeks and of controls (Experiment B).
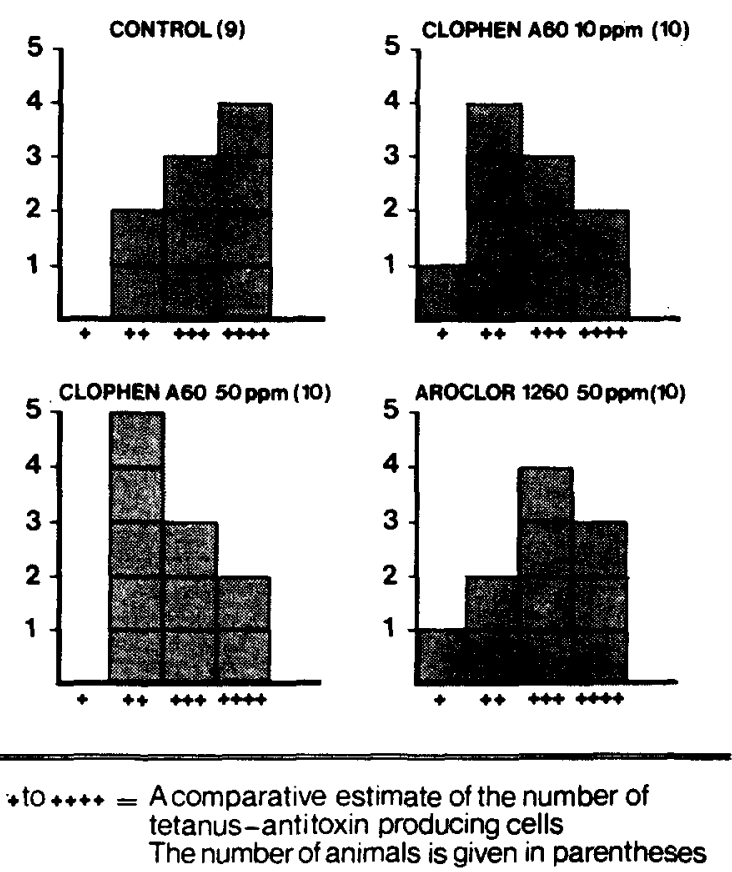

Fig. 6. Tetanus-antitoxin-containing cells in popliteal lymph nodes of female guinea pigs fed PCB for 6 weeks and of controls (Experiment $B$ ). 


\section{Experiment $B$}

PCB feeding at the 10 (Clophen A 60) and 50 ppm level (Clophen A 60; Aroclor 1260) did not affect the weight gain in female guinea pigs which were subjected to a primary and secondary stimulation with tetanus toxoid (Fig. 5). Relative thymus and liver weights at the $50 \mathrm{ppm}$ Clophen level were significantly reduced and increased, respectively. The absolute and relative uterus weights were significantly increased in all three experimental groups. No effect was noted on the weights of the other organs (popliteal lymph node, spleen, adrenals and ovaries), although the mean values in the Clophen $50 \mathrm{ppm}$ group did differ more from the control than the Aroclor $50 \mathrm{ppm}$ group.

The results of the serum antitoxin determinations and the leucocyte counts are given in Table III. Significantly decreased values are noted in both the $50 \mathrm{ppm}$ groups. A dose-related decrease was already seen in the $10 \mathrm{ppm}$ group. A semiquantification of the number of tetanus antitoxin-containing cells in the popliteal lymph nodes is given in Fig. 6. These cells are visualized in Fig. 7.

Small granulomas were seen at microscopic examination of the popliteal lymph nodes in the test and control groups. These granulomas are probably caused by the adjuvant $\left(\mathrm{AlPO}_{4}\right)$. No shift was found in the number of pyroninophilic cells and the number of follicles in the lymph nodes and spleens, nor was an effect found in the thymus (cortex-marrow relationship and number and morphology of the Hassal

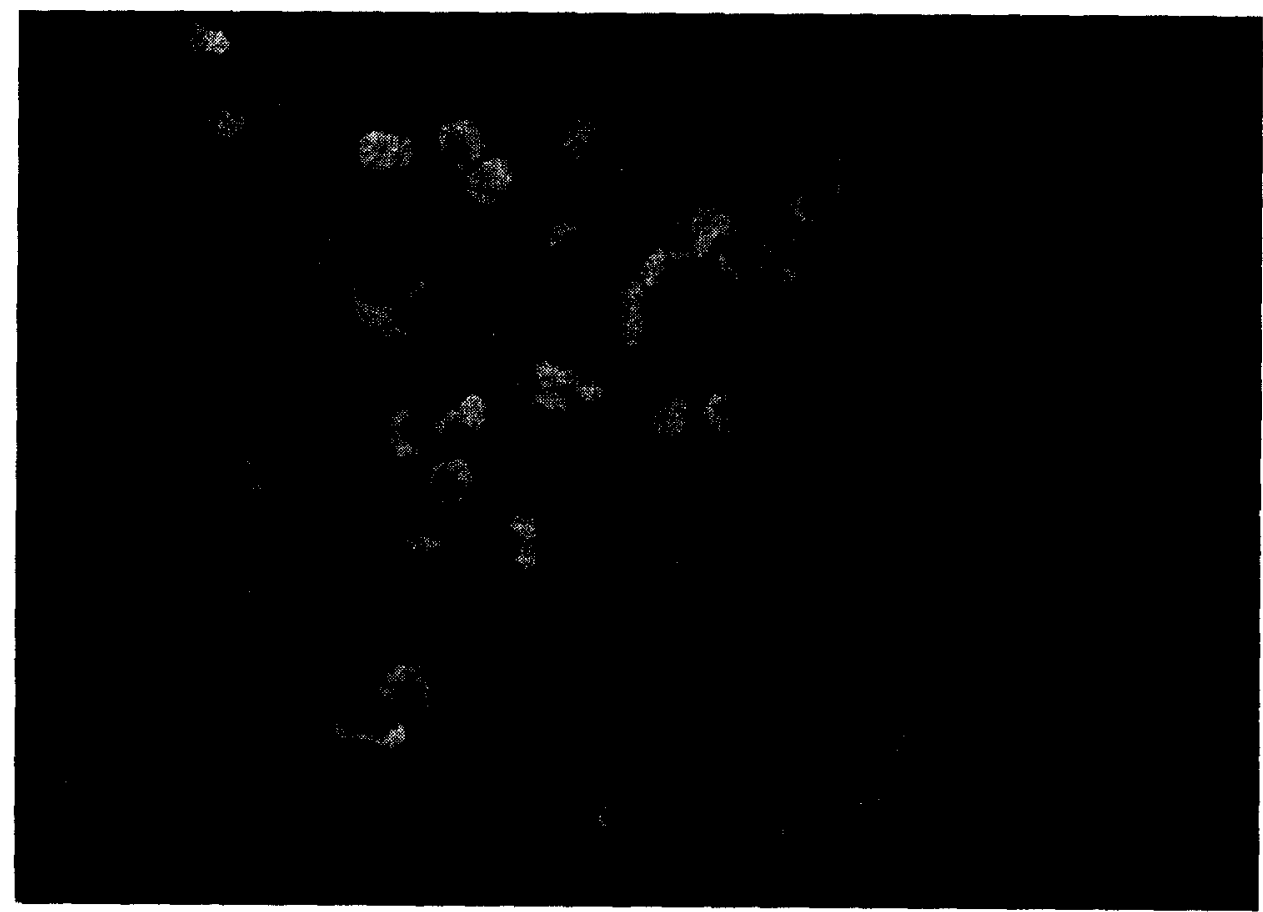

Fig. 7. Popliteal lymph node of a control guinea pig, killed one week after the second injection with tetanus toxoid (Experiment $B$ ). Note the tetanus antitoxin producing cells in the marrow. Indirect fluorescent antibody staining; $\times 565$. 
bodies). Vacuolization of liver parenchymal cells was seen in some animals from the $50 \mathrm{ppm}$ groups. Residue data of pooled liver samples are given in Table II.

TABLE III

EFFECT OF PCB FEEDING ON SERUM ANTITOXIN VALUES

AS MEASURED BY SINGLE RADIAL IMMUNODIFFUSION

AND ON LEUCOCYTE COUNTS IN FEMALE GUINEA PIGS STIMULATED

WITH TWO DOSES OF TETANUS TOXOID (Experiment $B)^{a}$

\begin{tabular}{lllll}
\hline $\begin{array}{l}\text { Dietary conc. } \\
\text { of PCB }(\mathrm{ppm})\end{array}$ & $\begin{array}{l}\text { No. of } \\
\text { animals }\end{array}$ & $\begin{array}{l}\text { Tetanus antitoxin } \\
\text { titre }(A E / \mathrm{m})^{b}\end{array}$ & \multicolumn{2}{c}{ White blood cells $\left(\times 10^{3} / \mathrm{mm}^{3}\right)$} \\
\hline Leucocytes & Lymphocytes \\
\hline 10 (Clophen A 60) & 10 & $69.6 \pm 13.7$ & $11.3 \pm 1.4$ & $5.9 \pm 1.4$ \\
50 (Clophen A 60) & 10 & $57.6 \pm 19.5$ & $9.6 \pm 3.3$ & $5.2 \pm 1.7$ \\
50 (Aroclor 1260) & 10 & $40.2 \pm 12.6^{\mathrm{e}}$ & $7.1 \pm 1.2^{\mathrm{e}}$ & $4.6 \pm 0.8^{\mathrm{c}}$ \\
& & $41.4 \pm 17.0^{\mathrm{e}}$ & $6.4 \pm 1.5^{\mathrm{e}}$ & $4.1 \pm 0.9^{d}$ \\
\hline
\end{tabular}

"Mean values $\pm \mathrm{SD}$.

- The antitoxin titres were expressed in International Units per $\mathrm{ml}(\mathrm{AE} / \mathrm{ml})$ on the basis of the international standard of tetanus antitoxin.

c $P \leqslant 0.025$.

d $P \leqslant 0.01$.

e $P \leqslant 0.005$.

\section{Experiment $C$}

After the immunization with Freund's Complete Adjuvant, a growth retardation was noted in the $50 \mathrm{ppm}$ Clophen group (Fig. 8) resulting in significantly lower

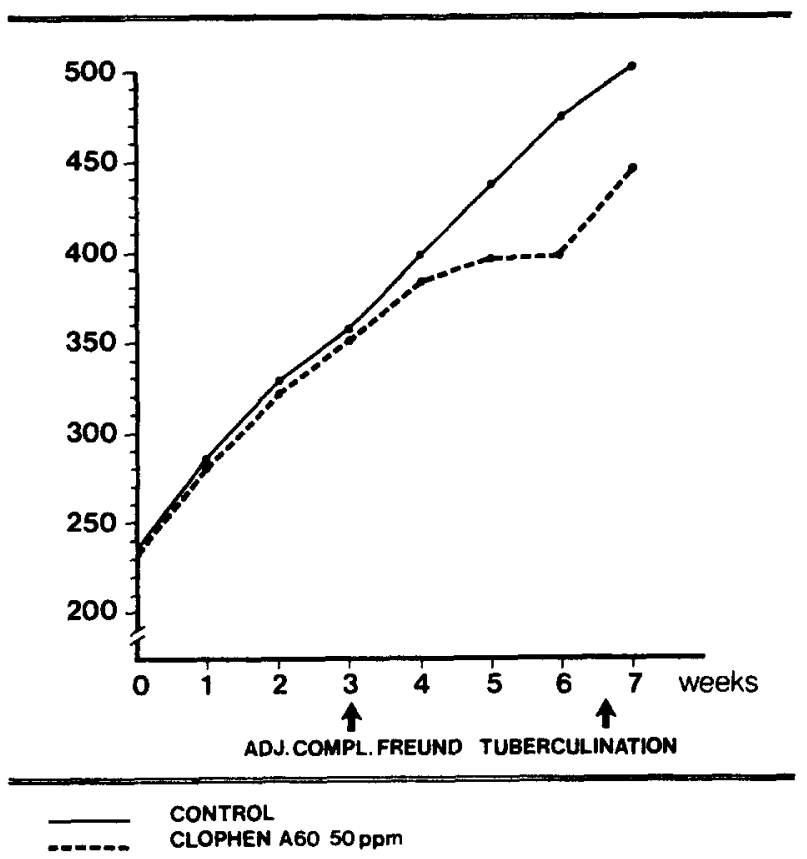

Fig. 8. Weight gain of Complete Freund's Adjuvant stimulated female guinea pigs fed PCB for 7 weeks and of controls (Experiment $C$ ). 
terminal body weights. All animals of the $250 \mathrm{ppm}$ group died during the experiment, showing growth retardation and roughening of the fur. The skin reactions, measured
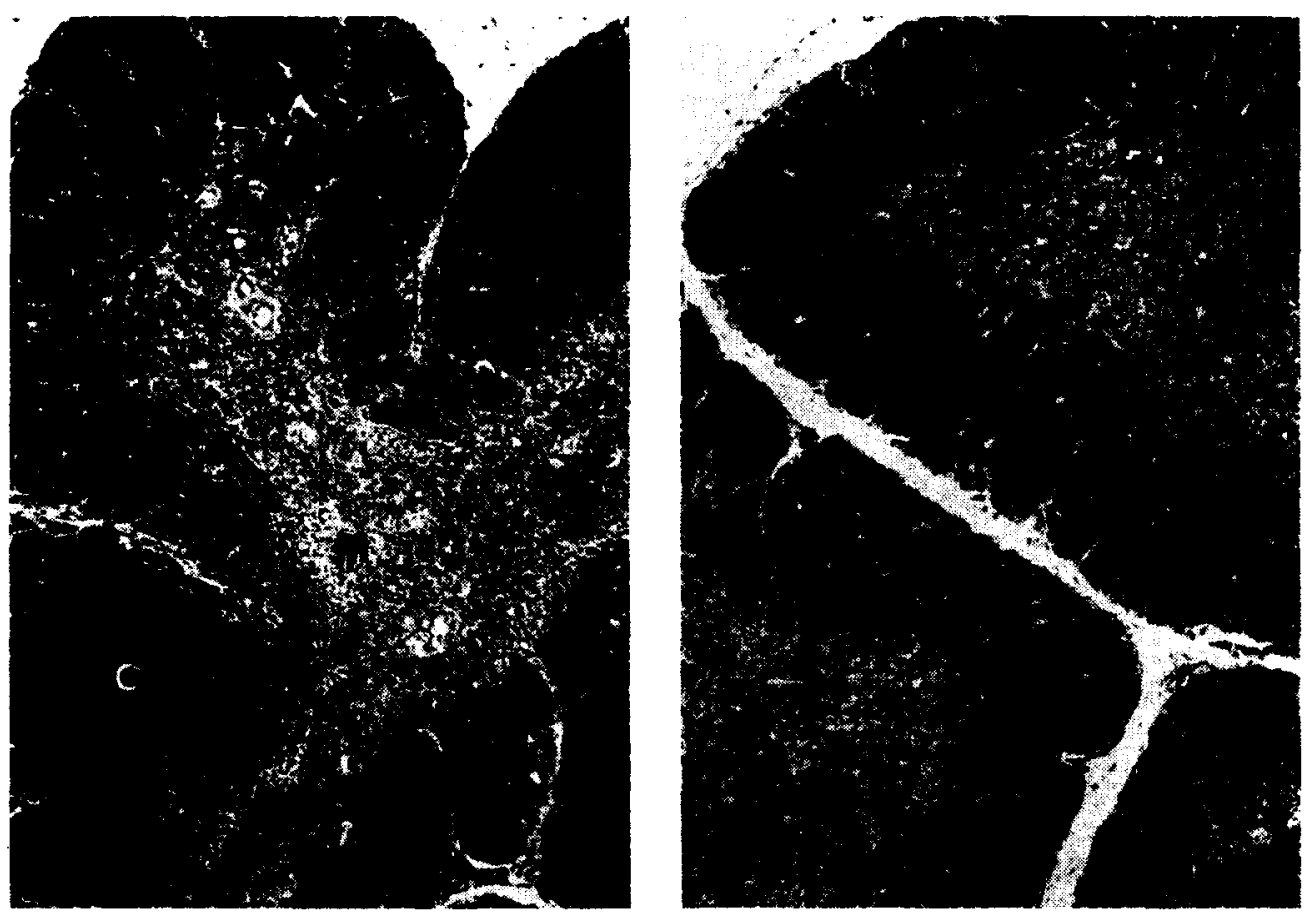

Fig. 9. Thymus of a control guinea pig from Experiment $C$, killed 28 days after stimulation with Freund's Complete Adjuvant. Note the cortex (C) and marrow (M). Haematoxylin-eosin; $\times 60$.

Fig. 10. Thymus of a killed guinea pig from the $50 \mathrm{ppm}$ group. A slight cortex atrophy can be seen. Haematoxylin-eosin; $\times 60$.

TABLE IV

EFFECT OF PCB FEEDING ON SKIN REACTION, THYMUS AND LEUCOCYTE COUNT IN FREUND'S COMPLETE ADJUVANT STIMULATED FEMALE GUINEA PIGS $(\text { Experiment } C)^{a}$

\begin{tabular}{|c|c|c|c|}
\hline $\begin{array}{l}\text { Dietary } \\
\text { conc. of }\end{array}$ & Skin reaction ${ }^{b}$ & Thymus & $\begin{array}{l}\text { White blood cells } \\
\left(\times 10^{3} / \mathrm{mm}^{3}\right)\end{array}$ \\
\hline $\begin{array}{l}\text { (Clophen } \\
\text { A 60) } \\
(p p m)\end{array}$ & $24 h$ & Abs. weight Rel. weight $\%$ cortex $^{c}$ & Leucocytes Lymphocytes \\
\hline
\end{tabular}

$\begin{array}{rccccccc}0 & 11.6 \pm 1.3 & 11.1 \pm 1.2 & 0.97 \pm 0.13 & 0.20 \pm 0.04 & 72.7 \pm 6.7 & 6.5 \pm 1.2 & 4.1 \pm 1.0 \\ 50 & 8.0 \pm 1.4^{f} & 6.9 \pm 1.6^{f} & 0.74 \pm 0.09^{f} & 0.17 \pm 0.02^{d} & 65.2 \pm 4.7^{e} & 5.0 \pm 1.4^{d} & 3.6 \pm 1.3\end{array}$

- Mean values $\pm \mathrm{SD}, 10$ animals per group.

- Diameter of skin reaction (in $\mathrm{mm}$ ) measured 24 and $48 \mathrm{~h}$ after tuberculination.

c Relative surface estimation of the cortex.

$P \leqslant 0.05$.

- $P \leqslant 0.01$.

$f \quad P \leqslant 0.005$. 
24 and $48 \mathrm{~h}$ after the tuberculination, were significantly reduced in the PCB group. The total number of white blood cells and the absolute and relative weights of the thymus were also reduced significantly. The reduced thymus weight was correlated with a decreased relative surface of the cortex (Table IV). The cortex atrophy is visualized in Fig. 9 (control), Fig. 10 (50 ppm), and Fig. 11 (250 ppm). Fig. 11 shows

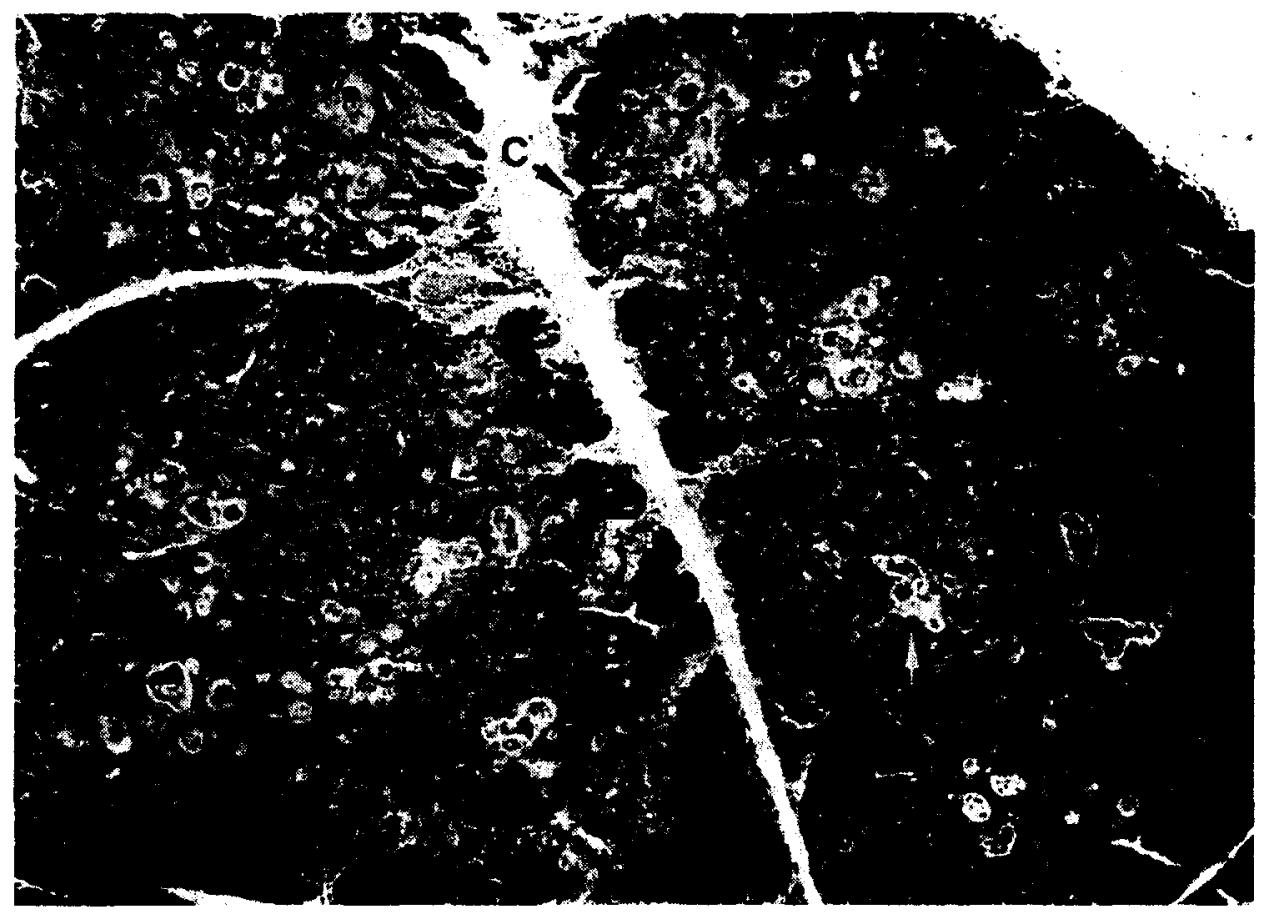

Fig. 11. Thymus of a guinea pig from the $250 \mathrm{ppm}$ group which died 9 days after stimulation with Freund's Complete Adjuvant. Note the severe cortex atrophy $(C)$ and the increase in size and number of Hassal bodies which are filled with polymorphonuclear leucocytes (arrow). This increase is due to the short period which passed since the immunization. Haematoxylin-eosin; $\times 60$.

a part of the thymus of an animal which died 9 days after immunization. An increased number of large cystic Hassal bodies filled with polymorphonuclear leucocytes can be seen. This pattern occurs 6-9 days after antigenic stimulation of, especially, the cell-mediated immune system (Kater, 1970). On histological examination of the intradermal lesions, a reduced number of large mononuclear cells and lymphocytes was seen in the $50 \mathrm{ppm}$ animals when compared with the controls. Granulomas were seen in popliteal lymph nodes in all groups. This is probably caused by Freund's Adjuvant. Absolute and relative liver weights were significantly increased in the $50 \mathrm{ppm}$ group. No effect was noted on the weight of the popliteal lymph nodes, spleens, adrenals and gonads. At histological examination of the other organs no effect at the $50 \mathrm{ppm}$ level was noted, except sometimes a focal liver necrosis and peripheral displacement of presumably cell organelles in the hepatocytes, resulting in a 
light eosinophilic staining of the cytoplasm. The lesions in the $250 \mathrm{ppm}$ group were essentially those as seen in the $250 \mathrm{ppm}$ group of Experiment $A$ and consisted of atrophy and depletion of the lymphoid system (popliteal lymph nodes, spleens and thymi) and liver damage. Hepatic porphyria did not occur. Liver residues are given in Table II.

\section{DISCUSSION}

From the results, it is concluded that feeding of PCBs at the level of $50 \mathrm{ppm}$ does have an immunosuppressive activity. Both the humoral (Experiments $A$ and $B$ ) and the cell-mediated immunity (Experiment $C$ ) were found to be suppressed. The reduced haemagglutination titres and the results of the fluorescent antibody staining found in Experiment $A$, after one dose of tetanus toxoid, indicate a suppression at the IgM level, while Experiment $B$, using the single radial immunodiffusion and fluorescent antibody techniques after primary and secondary antigenic stimulation, also suggests a suppression at the IgG level.

In a previous 8-week study (Vos and De Roij, 1972), suppression of the humoral immune response was already found at the $10 \mathrm{ppm}$ level, using less specific techniques. However, in the present and shorter experiments, some dose-related decreased immunologic response (though not significantly) was also seen at the $10 \mathrm{ppm}$ level.

Both the Clophen A 60 and Aroclor 1260 samples (Experiment B) were immunosuppressive, although the effects of Clophen were somewhat more marked: decreased relative thymus and increased relative liver weights. Perhaps, the presence of chlorinated dibenzofurans as impurities in the Clophen A 60 sample (Vos et al., 1970) may explain the difference.

Stress (release of glucocorticoids from the adrenals) is not considered responsible for the effects recorded at the $50 \mathrm{ppm}$ level. Even in the $250 \mathrm{ppm}$ group, major effects on the lymphoid system are due to the suppressive activity. The cachexia, the strongly reduced weights of the thymus, popliteal lymph node and, to a lesser degree, of the spleen with a histological appearance of lymphoid depletion, can be compared with the phenomena seen in runting or wasting disease, which is seen in neonatally thymectomised mice (Good et al., 1962).

Effects on the liver differed between the male and female animals. In the former, significant effects were seen at the $10 \mathrm{ppm}$ level, in the latter increased weights were noted in the $50 \mathrm{ppm}$ groups. The liver damage seen in the $250 \mathrm{ppm}$ animals was essentially that as seen in the PCB-treated rabbits (Vos and Beems, 1971; Vos and Notenboom-Ram, 1972). The PCB induced liver enlargement is probably due to proliferation of smooth surfaced membranes of the endoplasmic reticulum (SER) as was shown in the latter study in rabbits. Tissue fluorescence is not found in the animals which died from PCB treatment. Apparently PCB is not porphyrogenic in the guinea pig nor in some carnivorous birds: the cormorant and the heron(Koeman et al., 1972).

Evaluation of the danger of immunosuppression is difficult. But, in general, 
it can be said, that immunosuppression renders an individual more susceptible to infection, and more prone to develop cancer. Therefore, more attention should be paid to immune suppression, whether it comes from the presence of sublethal concentrations of pesticides $e . g$. DDT (Wassermann et al., 1971) and triphenyltin acetate (Verschuuren et al., 1970) from oncogenic viruses (Dent, 1972) or from general malnutrition (Nalder et al., 1972; Jose and Good, 1972).

\section{ACKNOWLEDGEMENTS}

The authors wish to thank Dr. M.P. C. Karelse (Medical Biological Laboratory, R. V. O., T. N. O., Rijswijk) for his suggestions and for the supply of the FITClabeled rabbit anti-tetanus serum, and also Miss $A$. van Heel for the serum determinations with the single radial immunodiffusion method. Thanks are also due to Dr. E. J. Ruitenberg (National Institute of Public Health, Bilthoven) for his helpful criticism.

\section{REFERENCES}

Dent, P. B., Progr. Med. Virol., 14 (1972) 1.

Elias, J. M., Stain Technol., 44 (1969) 201.

Flick, D. F., R. G. O'Dell and V. A. Childs, Poultry Sci., 44 (1965) 1460.

Friend, M. and D. O. Trainer, Science, 170 (1970) 1314.

Good, R. A., A. P. Dalmasso, C. Martinez, O. K. Archer, J. C. Pierce and B. W. Papermaster, J. Exp. Med., 116 (1962) 773.

Hansen, D. J., P. R. Parrish, J. I. Lowe, A. J. Wilson, Jr. and P. D. Wilson, Bull. Environ. Contam. Toxicol., 6 (1971) 113.

Jose, D. G. and R. A. Good, Lancet, (1972) 314.

Kater, L., Ph D. Thesis, Utrecht, The Netherlands, 1970.

Koeman, J. H., H. van Velzen-Blad, R. de Vries and J. G. Vos, TNO Nieuws, (1972) in press

Mancini, G., A. O. Carbonara and J. F. Heremans, Immunochemistry, 2 (1965) 235.

Nalder, B. N., A. W., Mahoney, R. Ramakrishann and D. G. Hendricks, J. Nutr.. 102 (1972) 535.

Stavitsky, A. B., J. Immunol. 72 (1954) 360.

Van der Waerden, B. L., Mathematische Statistik, Springer Verlag, Berlin, 1957, p. 269.

Verschuuren, H. G., E. J. Ruitenberg, F. Peetoom, P. W. Helleman and G. J. van Esch, Toxicol. Appl. Pharmacol., 16 (1970) 400.

Vos, J. G. and R. B. Beems, Toxicol. Appl. Pharmacol., 19 (1971) 617.

Vos, J. G. and Th. de Roij, Toxicol. Appl. Pharmacol., 21 (1972) 549.

Vos, J. G. and J. H. Koeman, Toxicol. Appl. Pharmacol., 17 (1970) 656.

Vos, J. G., J. H. Koeman, H. L. van der Maas, M. C. ten Noever de Brauw and R. H. de Vos, Food Cosmet. Toxicol., 8 (1970) 625.

Vos, J. G. and E. Notenboom-Ram, Toxicol. Appl. Pharmacol., (1972) in press.

Vos, J. G., J. J. T. W. A. Strik, C. W. M. van Holsteijn and J. H. Pennings, Toxicol. Appl. Pharmacol., 20 (1971) 232.

Wassermann, M., D. Wassermann, E. Kedar and M. Djavaherian, Bull. Environ. Contam. Toxicol., 6 (1971) 426.

Weibel, E. R., Morphometry of the Human Lung, Springer Verlag, Berlin, 1963, p. 20.

Weir, D. M., Handbook of Experimental Immunology, Blackwell Scientific Publications, Oxford and Edinburgh, 1967, p. 589. 